\title{
DAMPAK PSIKOLOGIS IBU HAMIL PADA MASA PANDEMI COVID-19
}

\author{
Literature Review
}

\author{
Atika Zahria Arisanti \\ Dosen Prodi Sarjana dan Pendidikan Profesi Bidan Universitas Islam Sultan Agung Semarang \\ atika.zahria@unissula.ac.id
}

\begin{abstract}
Abstrak
Latar Belakang : Pandemi COVID-19 semakin menyebar keseluruh dunia sehingga banyak menimbulkan masalah kesehatan. Pada ibu hamil yang merupakan subjek rentan sangat berisiko terhadap kesehatan ibu dan janin apabila terapapar. Ketakutan akan memeriksakan kehamilannya ke fasilitas kesehatan menyebabkan ibu merasa cemas akan kondisi janinnya serta kurangnya dukungan emisional dari keluarga selama masa social distancing.Tujuan : Untuk menelaah masalah psikologis ibu hamil selama masa pasndemi COVID-19 serta dampaknya bagi ibu hamil. Metode : metode dalam penulisan artikel ini adalah tinjauan literature yang terdapat dalam database jurnal kesehatan yaitu Lancet, Pubmed, Science Direct. Artikel yang terpilih berdasarkan full text, open acces, berbahasa Inggris dan Indonesia dan terbit tahun 2020. Hasil : Hasil studi literature melalui database dalam jurnal kesehatan menemukan sejumlah 26 Artikel di Lancet Global Health, 66 artikel di Pubmed, 5 artikel di Tandfonline, 10 artikel di Science Direct, dan 21 artikel di Google Schoolar. Selama periode kehamilan terjadi perubahan psikologis pada ibu hamil yang dapat meningkatkan kecemasan, stress bahkan sampai depresi dan trauma. Efek negative dari adanya gangguan psikologi pada ibu hamil dapat berakibat pada kesejahteraan janin yaitu pertumbuhan janin terhambat dan kelahiran premature.Kesimpulan : ibu hamil merupakan kelompok factor risiko tinggi yang rentan terhadap suatu masalag atau gangguan kesehatan salah satunya kesehatan mental. Faktor yang menyebabkan ibu hamil cemas selama masa pandemic antara lain : akses ke pelayanan kesehatan, ketakutan akan risiko terpapar virus, serta tidak ada dukungan emosional dari keluarga.
\end{abstract}

Kata Kunci : Psikologis, Ibu Hamil, Pandemi COVID-19

\section{PENDAHULUAN}

Coronavirus disease (COVID-19) disebabkan oleh virus Coronavirus 2 (SARS$\mathrm{CoV}-2$ ) sindrom pernafasan akut parah yang sangat berbahaya sehingga menyebar dengan sangat cepat. Penyakit pernapasan akut pertama kali dilaporkan muncul di kota Wuhan provinsi Hubei di China kemudian menyebar dengan cepat dan dinyatakan sebagai pandemi oleh World Health Organization (WHO).(1)

Di Indonesia, kematian ibu dan kematian neonatal masih menjadi tantangan besar dan perlu mendapatkan perhatian dalam situasi bencana COVID-19. Berdasarkan data dari Gugus Tugas Percepatan Penanganan COVID-
19 per tanggal 14 September 2020 pada kelompok ibu hamil, terdapat 4,9\% ibu hamil terkonfirmasi positif COVID-19 dari 1.483 kasus terkonfirmasi yang memiliki data kondisi penyerta. Data ini menunjukkan bahwa ibu hamil, bersalin, nifas dan bayi baru lahir juga merupakan sasaran yang rentan terhadap infeksi COVID-19 dan kondisi ini dikhawatirkan akan meningkatkan morbiditas dan mortalitas ibu dan bayi baru lahir. Hampir semua layanan kesehatan terdampak oleh penyakit COVID-19 termasuk pelayanan kesehatan maternal, neonatal dan pelayanan pada kesehatan ibu dan anak baik secara akses maupun kualitas, seperti ibu hamil menjadi 
JURNAL SEHAT MASADA VOLUME XV

enggan pergi ke puskesmas karena takut tertular, adanya anjuran penundaan pemeriksaan kehamilan dan kelas ibu hamil (2)

Terjadinya perubahan fisiologis semasa kehamilan mengakibatkan kekebalan parsial menurun sehingga data berdampak serius pada ibu hamil, hal inilah penyebab ibu hamil dijadikan kelompok rentan risiko terinfeksi COVID-19.(3). Situasi masa pandemi COVID19 meningkatkan kecemasan ibu hamil terkait dengan kesehatan janinnya dan mencemaskan keadaan dirinya jika tertular saat sedang periksa hamil di fasilitas kesehatan. Kehamilan yang disertai dengan kecemasan akan menurunkan imunitas ibu hamil sehingga ibu hamil akan semakin rentan terinfeksi COVID19 dan masa pemulihan menjadi lebih lama jika telah terinfeksi.(3).

Adanya pembatasan sosial (social distancing) mengakibatkan kurangnya dukungan social untuk banyak wanita hamil karena mereka terpisah dari orang tuanya. Dukungan social yang tidak konsisten merupakan salah satu factor risiko yang signifikan pada wanita hamil yang mengalami depresi. Dalam kondisi normal diperkirakan secara global sekitar 10\% ibu hamil menderita depresi terutama pada Negara berkembang.(4) Hal ini dapat diperburuk selama pandemi COVID-19 ketika wanita hamil mungkin memiliki akses yang terbatas ke layanan kesehatan mental. Di Cina, sebanyak 5.3\% ibu hamil mengalami gejala depresi, $6.8 \%$ mengalami kecemasan, $2.4 \%$ mengalami ketidaknyamanan fisik, 2,6 \% mengalami
NOMOR 2 Juli 2021

ISSN : 1979-2344

insomnia, dan $0.9 \%$ mengalami PostTraumatic Stress Disorder (PTSD).(5)

Terdapat hubungan yang signifikan antara pengetahuan, kecemasan dan motivasi dengan hasil pengetahuan yang baik dapat menurunkan tingkat kecemasan dan tetap memiliki motivasi untuk datang ke tenaga kesehatan untuk melakukan pemantauan kehamilan. Kecemasan akan kondisi kehamilannya, ditambah adanya pandemic Covid-19 dikhawatirkan akan meningkatkan kecemasan ibu hamil. Oleh karena itu pengetahuan dan pemahaman tentang Covid19 sangat penting untuk siap menghadapi pandemi dan cara penanggulangannya (6). Oleh karena itu sangat penting untuk menilai dampak psikologis dari wabah Covid-19.

Tujuan dari studi literature review ini untuk menelaah lebih dalam terkait masalah psikologis pada wanita hamil selama masa pandemic sehingga bisa mengidentifikasi dan mengurangi risiko komplikasi kehamilan akibat masalah kesehatan mental atau gangguan psikologis pada wanita hamil serta mengetahui kesiapan wanita hamil dalam menjalani kehamilan selama pandemic Covid19.

\section{METODE}

Metode dalam penulisan artikel ini merupakan literature review dengan menggunakan referensi dari jurnal dan artikel tentang kondisi psikologis, pengetahuan dan motivasi pada ibu hamil sebagai subjek rentan pada masa pandemic Covid-19. Artikel-artikel diperoleh melalui database Google Scholar, 
Pubmed, Springer, The Lancet, ELSEVIER, serta website WHO, Worldmeter dan Kementerian Kesehatan. Kriteria inklusi dan seleksi dokumen menggunakan kata kunci yaitu "kecemasan ibu hamil selama masa pandemic Covid-19” atau “ psychological impact for pregnant women during pandemic Covid-19". Penelusuran literature melalui database penulis menemukan sejumlah 26
Artikel di Lancet Global Health, 66 artikel di Pubmed, 5 artikel di Tandfonline, 10 artikel di Science Direct, dan 21 artikel di Google Schoolar. Artikel tersebut telah memenuhi kriteria yakni dipublikasikan di jurnal ilmiah, tersedia dalam free ful texr, open acces, berbahasa Inggris dan Indonesia dan dalam kurun waktu 1 tahun terakhir selama terjadinya pandemi Covid-19 yaitu tahun 2020.

\section{Tabel 1 Hasil Penelusuran Literatur yang Menggambarkan Kecemasan atau Masalah Psikologis Ibu Hamil Selama Pandemic COVID-19}

\begin{tabular}{|c|c|c|c|c|}
\hline No & Penulis & Tahun & Judul & Hasil \\
\hline 1 & $\begin{array}{l}\text { Gabrielle } \\
\text { Saccone,et,al }\end{array}$ & 2020 & $\begin{array}{l}\text { Psychological impact of } \\
\text { coronavirus disease in } \\
\text { pregnant women }\end{array}$ & $\begin{array}{l}\text { Berdasarkan usia kehamilan, wanita pada } \\
\text { trimester pertama kehamilan selama epidemi } \\
\text { COVID-19 mengalami kecemasan yang lebih } \\
\text { tinggi dan dampak psikologis yang lebih parah } \\
\text { dibandingkan pada trimester kedua atau ketiga } \\
\text { kehamilan. }\end{array}$ \\
\hline 2 & $\begin{array}{l}\text { Kotabagi } \\
\text { Phalguni,et.al }\end{array}$ & 2020 & $\begin{array}{l}\text { Anxiety and depression } \\
\text { levels among pregnant } \\
\text { women with COVID-19 }\end{array}$ & $\begin{array}{l}\text { Tingkat kecemasan ibu pada akhir pandemi di } \\
\text { Inggris menunjukkan tampak menurun dengan } \\
\text { tingkat depresi mengikuti pola yang serupa } \\
\text { seiring dengan meningkatnya informasi } \\
\text { kesehatan yang tersedia dan jaminan } \\
\text { kesehatan melalui media sosial }\end{array}$ \\
\hline 3 & $\begin{array}{l}\text { Yongjie } \\
\text { Zhou,et al }\end{array}$ & 2020 & $\begin{array}{l}\text { The prevalence of } \\
\text { pshychiatric symptoms of } \\
\text { pregnant and non- } \\
\text { pregnant women during } \\
\text { the COVID-19 epidemic }\end{array}$ & $\begin{array}{l}\text { Selama epidemi COVID-19 di China, wanita } \\
\text { hamil menghadapi masalah mental yang } \\
\text { disebabkan oleh COVID-19 yakni } \\
\text { menunjukkan gejala depresi, kecemasan, } \\
\text { insomnia, dan PTSD yang lebih sedikit } \\
\text { daripada wanita yang tidak hamil. }\end{array}$ \\
\hline 4 & $\begin{array}{l}\text { Hendriani } \\
\text { dwi,dkk }\end{array}$ & 2021 & $\begin{array}{l}\text { Peran suami dalam } \\
\text { gangguan kecemasan dan } \\
\text { stress pada ibu hamil } \\
\text { selama } \\
\text { COVID-19 pandemic }\end{array}$ & $\begin{array}{l}\text { Dukungan suami bukanlah menjadi faktor } \\
\text { utama selama pandemi COVID-19 yang dapat } \\
\text { dilakukan sebagai upaya menurunkan tingkat } \\
\text { kecemasan dan stress. } \\
\text { Kata }\end{array}$ \\
\hline 5 & $\begin{array}{l}\text { Lopez, } \\
\text { Herman, et al }\end{array}$ & 2020 & $\begin{array}{l}\text { Mental health of pregnant } \\
\text { women during the } \\
\text { COVID-19 pandemic: A } \\
\text { longitudinal study }\end{array}$ & $\begin{array}{l}\text { Pada wanita hamil menunjukkan peningkatan } \\
\text { depresi, kecemasan dan pengaruh negative } \\
\text { lainnya dibandingkan dengan wanita yang } \\
\text { tidak hamil, perlu adanya penyediaan } \\
\text { pelayanan kesehatan untuk mengoptimalkan } \\
\text { perawatan kesehatan perinatal. }\end{array}$ \\
\hline
\end{tabular}

\section{HASIL DAN PEMBAHASAN}

Artikel ini mengidentifikasi database berdasarkan beberapa kriteria, diantaranya jurnal atau artikel dapat di akses, full text, bahasa inggris, dan terbit tahun 2020, yang Jurnal Penelitian Kesehatan STIKes Dharma Husada Bandung diperoleh sebanyak 128 jurnal. Kemudian didapatkan berdasarkan judul diperleh 25 studi yang relevan. Dari 25 studi yang relevan kemudian dianalisis berdasarkan kriteria dan 
dihasilkan 20 artikel yang tidak eligible dan 7 artikel kemudian dianalisis.

Coronavirus disease 2019 merupakan penyakit menular varian baru yang menyebabkan sindrom pernapasan akut parah. Pandemic Covid-19 salah satunya menyerang ibu hamil. Efek infeksi virus SARS-CoV-2 pada kehamilan berkontribusi terhadap peningkatan morbiditas dan kematian ibu hamil yaitu dua kali lebih tinggi untuk wanita hamil daripada wanita tidak hamil. Ibu hamil berisiko tinggi dikarenakan adanya perubahan imunologi dan fisiologi system gestasional dalam system tubuh ibu hamil sehingga dapat meningkatkan risiko (7)(8).

Sebagian besar penelitian tentang COVID-19 dan kaitannya dengan kehamilan telah dilakukan, hanya masih berfokus pada efek fisik pada ibu hamil yang terinfeksi, pencegahan dan penatalaksanaan penularannya. Pentingnya untuk tidak mengabaikan pengaruh kondisi psikologis pada wanita hamil selama pandemic karena kesehatan psikologis dapat dikaitkan dengan risiko jangka pendek dan jangka panjang bagi ibu dan janinnya.(9)

Beberapa studi melaporkan kerentanan wanita hamil terhadap perubahan emosional, psikologis dan stress menjadi faktor risiko yang dapat memperparah efek negative dari pandemi COVID-19 apalagi jika terdapat penyakit komorbid yang menyertainya. Hasil studi menunjukkan bahwa ibu hamil yang mengalami rasa kecemasan bahkan sampai stress diakibatkan karena berbagai macam masalah diantaranya adalah ekonomi, keluarga, pekerjaan, serta kekhawatiran terhadap kehamilan dan persalinannya kelak (10)

Hasil penelitian menunjukkan adanya hubungan antara tingkat pendidikan dengan kecemasan ibu hamil, karena tingkat pendidikan yang rendah mengakibatkan kurangnya pengetahuan ibu dalam menghadai masalah dan mengambil tindakan dalam menjaga kesehatan kehamilannya semasa pandemi covid-19 (11).

Sebuah studi yang dilakukan di China, berdasarkan usia gestasi didapatkan bahwa wanita hamil pada trimester pertama memiliki tingkat kecemasan sedang sampai berat (28\%) dibandingkan dengan kehamilan trimester kedua dan ketiga. Kemudian dari 18 wanita hamil yang melahirkan selama masa pandemi, sebanyak $16 \%$ melahirkan secara sesar karena permintaan sendiri. Hal ini terjadi karena kecemasan akan terjadinya trauma atau cidera pada janin, khawatir jika bayinya meninggal dan faktor emosinal ibu. (12)

Dalam situasi normal, diperkirakan secara global sekitar $10 \%$ ibu hamil menderita gangguan jiwa, terutama depresi dan bahkan lebih tinggi (16\%) di negara berkembang (Zeng et al., 2020). Hal ini dapat diperburuk dengan pandemi COVID-19 saat ini ketika wanita hamil mungkin mengalami hambatan terhadap akses ke layanan kesehatan mental. Di China, sebanyak 5,3\% ibu hamil mengalami gejala depresi, 6,8\% mengalami kecemasan, 2,4\% mengalami ketidaknyamanan fisik, 2,6\% mengalami insomnia, dan $0,9 \%$ mengalami Post- Traumatic Stress Disorder (5) 
Pada sebuah studi yang menunjukkan hubungan kecemasan, pengetahuan dan motivasi ibu hamil pada masa pandemic covid19 didapatkan hasil bahwa terdapat hubungan Pengetahuan dan kecemasan dengan motivasi $(\mathrm{p}=0,004)$. Hasil analisis menunjukkan ada hubungan antara pengetahuan dengan motivasi. Setiap peningkatan pengetahuan akan meningkatkan motivasi sebesar 1,54 poin $(\mathrm{b}=1,54 ; \mathrm{p}=0,040)$. Hasil analisis juga menunjukkan terdapat hubungan antara kecemasan dengan motivasi. Setiap penurunan kecemasan akan meningkatkan motivasi sebesar 0,34 poin $(b=0,34 ; p=0,009)$. Adjusted $\mathrm{R}$ Square $=22,1 \%$ mengandung arti bahwa kedua variabel didalam regresi linier ganda yaitu pengetahuan dan kecemasan menjelaskan variansi adanya motivasi sebesar $22,1 \%$ (6). Hasil tersebut menunjukkan bahwa apabila tingkat pengetahuan yang semakin baik tentang COVID-19 akan meminimalkan kecemasan pada ibu hamil sehingga akan meningkatkan kemungkinan ibu untuk patuh dalam memeriksakan kehamilannya, apabila terdapat ibu hamil yang memiliki karakteristik dan latar belakang yang sama, maka ibu dengan pengetahuan yang lebih tinggi akan memiliki tingkat kepatuhan yang lebih baik dalam memeriksakan kehamilannya

Kecemasan yang terjadi diimbangi dengan adanya pengetahuan atau informasi tentang COVID-19 sehingga ibu hamil diperkirakan mampu mengendalikan kecemasannya. Kecemasan sering terjadi, dan dapat berdampak negatif pada kualitas hidup masyarakat. Kecemasan pada kehamilan merupakan reaksi emosional yang terjadi pada ibu hamil yang berhubungan dengan kekhawatiran ibu tentang kesejahteraan diri dan janinnya, keberlangsungan kehamilan, persalinan, masa setelah persalinan dan ketika telah berperan menjadi ibu (13).

Kecemasan dipicu oleh berbagai macam faktor, salah satunya ialah pengetahuan Ketika pasien memiliki pemahaman yang baik tentang kecemasannya, dia dapat mulai mempelajari keterampilan baru untuk mengelola gejala dengan lebih baik. Pemahaman yang baik tersebut diharapkan dapat mengurangi kecemasan ibu hamil terhadap pandemic Covid-19

Peningkatan kasus covid-19 semakin menyebar disejumlah Negara membuat pemerintah memberlakukan kebijakan untuk pencegahan penularan virus dengan menerapkan social distancing dan pshycal distancing, isolasi dan perubahan ekstrim dalam kehidupan sehari-hari dapat meningkatkan risiko stress pada subjek rentan seperti ibu hamil(12)

Kebijakan social distancing mengkibatkan kurangnya dukungan sosial pada wanita hamil karena terpisah dari orang terdekat mereka seperti suami, anak, orang tua dll. Dukungan social yang tidak konsisten merupakan salah satu faktor risiko yang signifikan terhadap terjadinya stress bahkan depresi.(14)

Hal ini didukung dengan penelitian yang menyimpulkan bahwa dukungan suami terhadap ibu hamil selama pandemic Covid-19 menunjukkan dukungan positif/baik sebesar 
JURNAL SEHAT MASADA VOLUME XV

69\% sedangkan prevelensi kecemasan pada ibu selama masa pandemic sebesar $47 \%$ dan prevalensi stress sebesar 24\% dengan sebagian besar ibu hamil yang diteliti pada studi ini memiliki tingkat kecemasan dan stress yang rendah.(15) Semakin tinggi dukungan suami terhadap ibu akan memmpengaruhi kejadian tingkat kecemasan dan stress selama proses kehamilan. Pengaruh dukungan suami yang positif dapat melindungi kesehatan mental ibu selama masa kehamilannya. Kondisi fisik ibu selama hamil akan mempengaruhi keadaan sebuah bentuk perhatian baik secara fisik maupun psikologis yang diberikan oleh pasangan terhadap ibu hamil untuk menjaga kesehatan mental ibu hamil.

Berdasarkan hasil penelitian menunjukkan bahwa di beberapa Negara, ibu hamil mengalami perubahan psikologis yang signifikan dari sebelum terjadi Covid -19 dan saat Covid -19. Tingginya perubahan tingkat kecemasan dan stress pada ibu hamil disebabkan perubahan perilaku yang terjadi selama masa kehamilan di masa pandemi COVID-19 berpengaruh pada rendahnya motivasi ibu hamil yaitu mengurangi kunjungan pemeriksaan oleh bidan atau dokter secara langsung, takut untuk berinteraksi diluar karena tingginya angka kejadian infeksi COVID-19 yang tinggi karena takut tertular, ketakutan terhadap ketersediaan makanan yang kurang, hingga konflik rumah tangga yang terjadi. Faktor tersebut secara langsung mengubah tingkat kecemasan dan stress ibu emosional (16). Dukungan suami adalah

selama pandemi COVID-19 meningkat signifikan (17)

Hal ini berbeda dengan penelitian yang dilakukan oleh Nugraheni,dkk, menunjukkan bahwa terdapat hubungan antara kecemasan dengan motivasi. Kecemasan dimanifestasikan oleh gangguan mood, pemikiran, perilaku, dan aktivitas fisiologis yang jika pada kategori berat akan disertai gangguan tidur, konsentrasi, fungsi sosial dan/atau pekerjaan. Selain itu jika sudah menjadi gangguan kecemasan akan timbul kegelisahan, perasaan tegang atau gelisah, mudah lelah, kesulitan dalam berkonsentrasi atau pikiran menjadi kosong, mudah tersinggung, ketegangan otot, dan mudah tersinggung. (18) Pada hasil penelitian menunjukkan hal ini tidak dialami oleh ibu hamil.Penelitian sebelumnya mengatakan bahwa kecemasan timbul karena adanya sesuatu yang tidak jelas atau tidak diketahui sehingga muncul perasaan yang tidak tenang, rasa khawatir, atau ketakutan (19). Oleh karena adanya pengetahuan yang baik dan tingkat kecemasan yang masih pada kategori wajar diharapkan ibu hamil tetap disiplin dalam melakukan pemeriksaan kehamilan. Pemeriksaan kehamilan merupakan salah satu tahapan penting menuju kehamilan yang sehat dan merupakan hal yang wajib dilakukan oleh ibu hamil Kunjungan antenatal rutin dapat membantu dalam mengidentifikasi dan mengurangi risiko ibu dan bayi selama kehamilan. Pemeriksaan kehamilan merupakan bagian dari Antenatal Care (ANC). ANC akan mencegah berbagai masalah yang terjadi saat hamil termasuk risiko kematian ibu akibat 
kehamilan (20). Berdasarkan hasil penelitian menunjukkan bahwa motivasi ibu hamil dalam memeriksakan kehamilannya didaptkan hasil bahwa yang menyatakan motivasinya tinggi sebanyak 64 orang (93\%) dan yang menyatakan motivasi rendah sebanyak 5 orang (7\%).

Wanita hamil dianggap sebagai subjek rantan yang memiliki faktor risiko. Beberapa penelitian melaporkan bahwa wanita hamil rentan terhadap perubahan emosi dan stress karena akan berdampak pada ibu dan janinnya. Kondisi tersebut dapat meningkatkan risiko persalinan premature bahkan risiko kematian bayi (21). Gangguan emosional seperti depresi, kecemasan, dan stres ibu selama kehamilan berdampak pada bayi yakni perkembangan janin yang buruk, kelahiran prematur (preterm birth) dan bayi berat lahir rendah (BBLR). Anak-anak dengan preterm birth atau BBLR berisiko mengalami masalah emosional atau kognitif, termasuk hiperaktif, kecemasan, atau keterlambatan bahasa (22)

Pada masa pandemi, ibu hamil harus tetap melakukan pemeriksaan antenatal guna mengurangi dan mencegah factor risiko terjadinya gangguan psikologis. Beberapa upaya yang bisa dilakukan untuk menekan penularan virus dan ibu hamil tetap bisa mendapatkan pelayanan antenal, dukungan, dan perawatan yang dibutuhkan selama masa pandemi antara lain dengan konsultasi telemedicine denan bidan atau dokter(23)

Beberapa studi mengatakan bahwa pelayanan antenatal harus tetap dilakukan oleh ibu hamil semasa pandemi salah satu Jurnal Penelitian Kesehatan STIKes Dharma Husada Bandung diantaranya dengan metode drive-through, yaitu ibu hamil tetap berada di mobil saat pemeriksa menilai status kesehatan ibu hsmil, sehinggs mengurani kontak dan paparan dari tenaga medis kepada ibu hamil. Pelayanan ini meliputi : pemeriksaan tekanan darah, pemeriksaan kesejahteraan janin berbasis ultrasound, dan skrinning laboratorium darah untuk menemukan secara dini adanya anemia. Pelayanan antenatal drive-through tetap ada interaksi tatap muka antara ibu hamil dan tenaga kesehatan dengan tetap mematuhi protocol kesehatan yaitu menjaga jarak, menggunakan masker dan alat pelindung diri lainnya, interaksi ini diharapkan mampu mengurangi kecemasan ibu hamil akibat takut untuk periksa ke fasilitas pelayanan keesehatan

\section{KESIMPULAN}

Kecemasan merupakan keadaan yang terjadi karena adanya perubahan dan pengalaman baru ditandai dengan perasaan takut yang tidak jelas penyebabnya dan tidak didukung oleh situasi yang ada dan disebabkan oleh berbagai faktor antara lain usia kehamilan, pendidikan ibu, pengetahuan ibu dan motivasi ibu.

Pada masa pandemi COVID-19, kejadian gangguan psikologis pada ibu hamil mengalami peningkatan dan berdampak negatif dikarenakan adanya perasaan cemas dan takut akan keselamatan dirinya dan bayinya serta takut untuk bertemu dengan tenaga kesehatan di fasilitas pelayanan kesehatan karena khawatir akan terpapar oleh virus. Perubahan 
emosional yang terjadi selama kehamilan dikarenakan fungsi hormonal juga dapat memicu kestabilan emosi pada ibu hamil sehingga dapat berdampak pada kesehatan psikologis ibu dan kesejahteraan janin.

Perlu adanya upaya untuk dapat menekan gangguan psikologis yang terjadi pada ibu hamil yaitu dengan adanya dukungan dari keluarga seperti suami, anak dan orang tua. Kemudia tetap kontak dengan tenaga kesehatan dengan cara tellemedice atau metode drive-through untuk mengurangi kecemasan ibu karena sudah mendapatkan konseling dari tenaga kesehatan.

\section{DAFTAR PUSTAKA}

1. WHO. Advice on the use of masks in the community, during home care and in health care settings in the context of the novel coronavirus (2019-nCoV) outbreak [Internet]. 2020. Available from: https://www.who.int/ith/2020-24-01outbreak-of-Pneumonia-caused-by-newcoronavirus/en/

2. Kemenkes RI. Pedoman pelayanan antenatal, persalinan, nifas, dan bayi baru lahir di Era Adaptasi Baru. 2020. 98 p.

3. Liang H, Acharya G. Novel corona virus disease ( COVID-19) in pregnancy : What clinical recommendations to follow? 2020;439-42.

4. Liang-Nan Zeng. Since January 2020 Elsevier has created a COVID-19 resource centre with free information in English and Mandarin on the novel coronavirus COVID- 19. The COVID-19 resource Jurnal Penelitian Kesehatan STIKes Dharma Husada Bandung centre is hosted on Elsevier Connect, the company's public news and information. 2020;(January):2020-2.

5. Zhou Y, Shi H, Liu Z, Peng S, Wang R, Qi $\mathrm{L}$, et al. The prevalence of psychiatric symptoms of pregnant and non-pregnant women during the COVID-19 epidemic. Transl Psychiatry [Internet]. 2020; Available from: http://dx.doi.org/10.1038/s41398-02001006-x

6. Hubaedah A. Ibu Hamil pada Masa Pandemi COVID-19 di Indonesia: Pengetahuan, Kecemasan dan motivasi. Wiraraja Med J Kesehat. 2020;11(1):1-9.

7. Hayakawa S, Komine-Aizawa S, Mor GG. Covid-19 pandemic and pregnancy. J Obstet Gynaecol Res. 2020;46(10):195866.

8. Rajewska A, W M-B, J L-K, M S, S K, A T. COVID-19 and pregnancy - where are we now? A review. J Perinat Med [Internet]. 2020;48(5):428-34. Available from: https://pubmed.ncbi.nlm.nih.gov/32452195/

9. Editor LTO. Anxiety and depression levels among pregnant women with. 2020;(May):953-4.

10. Diki Retno Yuliani FNA. KECEMASAN IBU HAMIL DAN IBU NIFAS PADA MASA PANDEMI COVID-19 DI KECAMATAN BATURRADEN. 2020;2(2).

11. Citra Dewi AD, Nurbaiti M, Surahmat R, Putinah P. Kecemasan pada Ibu Hamil di Masa Pandemi Covid 19 di RSUD Ibnu 
Sutowo Baturaja. J Smart Keperawatan. 2021;8(1):64.

12. Gabriele Saccone, MD;Alessia Florio M, Federica Aiello, MD;Roberta Venturella, MD;Maria Chiara De Angelis M, Mariavittoria Locci M. free information in English and Mandarin on the novel coronavirus COVID- Psychological impact of coronavirus disease 2019 in pregnant women. Psychol impact coronavirus Dis 2019 pregnant women [Internet]. 2020;(January). Available from:

https://www.ncbi.nlm.nih.gov/pmc/article s/PMC7204688/pdf/main.pdf

13. Zaid A, Barakat M, Al-qudah RA, Albetawi S, Hammad A. Knowledge and awareness of community toward COVID19 in Jordan : A cross-sectional study. 2020;11(7):135-42.

14. Howell EA. Social support during the postpartum period: Mothers' views on needs, expectations, and mobilization of support. 2014;17(4):616-23. Available from:

https://www.ncbi.nlm.nih.gov/pmc/article s/PMC3518627/pdf/nihms386158.pdf

15. Hendriani D, Widyastuti HP, Putri RA, Puspitaningsih R. Peran Suami Dalam Gangguan Kecemasan Dan Stress Pada Ibu Hamil Selama Pandemi Covid-19. Mahakam Midwifery J [Internet]. 2021;6(1):28-36. Available from: http://www.ejournalbidan.poltekkeskaltim.ac.id/ojs/index.php/midwifery/artic le/view/166
16. Cheng ER, Rifas-shiman SL, Perkins ME, Wright R. The Influence of Antenatal Partner Support. 2016;25(7):672-9.

17. S.S R, Y H, M.D.A P. Dampak Coronavirus Disease 2019 (Covid-19) pada Kehamilan Sejak Desember 2019 Hingga Agustus 2020 Melalui Tinjauan Literatur. Wal'afiat Hosp J. 2020;2(1):1422.

18. Munir, S., Gondal, A.Z., \& Takov, V. Generalized anxiety disorder. 2019; Available from: https://www.ncbi.nlm.nih.gov/books/\%0A NBK441870

19. PH, L., Susanti, Y., \& Putra DEA. Hubungan Karakteristik Keluarga Dengan Tingkat Ansietas Saat Menghadapi Kekambuhan Pasien Gangguan Jiwa. J Heal Sci [Internet]. 2018;2(1):46. Available from: https://doi.org/1 0.24269 lijhs.v2i1.664

20. Aslinda H, Hasrul. Hubungan Kejadian Pandemi COVID 19 Dengan Kecemasan Ibu Hamil Trimester Ketiga. J Keperawatan Muhammadiyah. 2021;6(2):151-5.

21. Ver M, Andr ML. Mental health of pregnant women during the COVID-19 pandemic: A longitudinal study. 2020;(January). Available from: https://www.ncbi.nlm.nih.gov/pmc/article s/PMC7657008/pdf/main.pdf

22. Ibanez G, Bernard JY, Rondet C, Peyre H, Forhan A, Kaminski M, et al. Effects of Antenatal Maternal Depression and Anxiety on Children' s Early Cognitive 
Development : A Prospective Cohort

Study. 2015;1-16.

23. Bender WR, Hirshberg A, Srinivas $\mathrm{S}$, Coutifaris P, Acker A. The Psychological Experience of Obstetric Patients and Health Care Workers after Implementation of Universal SARS-CoV-
2 Testing. 2020;19104.

24. Turrentine M, Ramirez M, Monga M, Gandhi M. Rapid Deployment of a DriveThrough Prenatal Care Model in Response to the Coronavirus Disease 2019. 2020;136(1):1-4. 